ELŻBIETA SMOLARKIEWICZ

\title{
MIGRACJE A PRZEMIANY MIAST
}

\begin{abstract}
Smolarkiewicz Elżbieta, Migracje a przemiany miast [Migration and urban transformation] edited by J. Kubera, Ł. Skoczylas - „Człowiek i Społeczeństwo”, vol. XXXVII, Poznań 2014, pp. 27-40, Adam Mickiewicz University Press. ISBN 978-83-232-2764-9. ISSN 0239-3271.
\end{abstract}

Migrations throughout history constitute one of the most important mechanisms affecting urban development. The conditions of the specificity of the Polish post-war migration determined the linking of the processes of industrialization and urbanization differently than in Western Europe. Thanks to the impressive efforts that ultimately limited the influx of people there has been a slowing down of urban sprawl. The contemporary nature of migration in urban space designates changes in both the economic structure and metropolisation processes. The reversal of the traditional direction of migration generates an increased scale of commuting and disseminates the category of shuttle migrants. The process of metropolisation too enforces change in the migrant profile. There is a strong demand from migrants for the requirement to have a specific socio-cultural capital. The metropolisation differentiates the migration stream, determining the specificity of the city.

Elżbieta Smolarkiewicz, Uniwersytet im. Adama Mickiewicza w Poznaniu, Instytut Socjologii, ul. Szamarzewskiego 89c, 60-568 Poznań, Poland.

Rozwojowi społeczeństw nieodłącznie towarzyszyło powstawanie i rozwój miast, których struktura przestrzenna, granice, typ zabudowy, charakter struktury społecznej, infrastruktura etc. oddawały swoistość ich twórców i mieszkańców. Można sprzeczać się o moment powstania pierwszego miasta, wszak odkrycia archeologiczne oddalają ten moment w czasie. Niezależnie jednak od epoki i miejsca, których specyfika w oczywisty sposób decydowała o charakterze miasta, odgrywało ono jako ośrodek polityczny (o różnym stopniu autonomii politycznej), kulturowy, usługowo-handlowo-produkcyjny i administracyjny istotną rolę z punktu widzenia funkcjonowania i rozwoju całych społeczeństw.

Zgodnie z linearnym ujęciem rozwoju miast (koncentrującym się głównie na kontekście europejskim) różne czynniki były w różnych okresach za ów rozwój odpowiedzialne, choć skala zasięgu oddziaływania ośrodków 
miejskich $\mathrm{i}$ ich znaczenie było $\mathrm{w}$ minionych epokach niewątpliwie niewspółmiernie mniejsze niż współcześnie. Starożytne miasta swą siłę i rozkwit opierały na czynnikach politycznych, zatem ich wielkość, poziom zamożności czy struktura społeczno-gospodarcza były odzwierciedleniem potęgi imperium, w skład którego wchodziły. Upadek imperium oznaczał więc kurczenie się, także w sensie ludnościowym, miast. Od średniowiecza w zasadzie po początek rewolucji przemysłowej miasta pełniły głównie rolę ośrodków wymiany i tym samym opierały swój rozwój przede wszystkim na handlu i rzemiośle, co przekładało się na rozdrobnienie osadnictwa miejskiego. W Europie największy rozwój, choć jego skala była nieporównywalnie mniejsza niż $\mathrm{w}$ miastach starożytności, cechował ośrodki kupieckie i portowe, szczególnie włoskie i hanzeatyckie. Stopniowy rozwój miast tej epoki oznaczał także rozszerzanie się zakresu pełnionych funkcji - z głównie polityczno-gospodarczych także na kulturowe czy administracyjne. I choć miasta minionych czasów $\mathrm{w}$ niewielkim stopniu przypominały współczesne, to mechanizm współwarunkujący ich powstawanie, a potem rozwój, pozostał niezmienny - migracje ludności z ośrodków o niższym poziomie rozwoju (Majer 2010: 120-124). Choć migracje do miast nie są zjawiskiem nowym, to w różnych okresach historycznych w inny sposób wyznaczały one kierunek i charakter zmian miast. Krótki zarys zmian ludnościowych i ich konsekwencji pozwoli na określenie specyfiki współczesnych tendencji migracyjnych i ich znaczenia dla ośrodków miejskich.

Znaczenie migracji jako czynnika współokreślającego rozwój miast stało się wyraźnie widoczne wraz z nadejściem rewolucji przemysłowej ${ }^{1}$, która zniosła bariery istotnie ograniczające napływ migrantów do miast. Tym, co hamowało $\mathrm{w}$ epoce preindustrialnej swobodny przepływy ludności, były przede wszystkim odległość (a w zasadzie niemożność jej pokonania wywołana słabo rozwiniętymi środkami transportu) i czas („prymitywne” środki transportu czyniły podróż długotrwałą i uciążliwą, często tym samym nieopłacalną). Bariery te pozostawały $w$ relacji do ograniczeń, jakie niosła ze sobą produkcja uzależniona od działania sił natury, wiążąca człowieka z miejscem zamieszkania (Jałowiecki, Szczepański 2002: 55-61). Zdobycze techniki epoki przemysłowej nie tylko umożliwiły zmianę profilu i form gospodarki, ale także uwolniły jednostki i zbiorowości od "przymusu” bycia

${ }^{1}$ Z punktu widzenia rozwoju miast określenie „rewolucja przemysłowa” można uznać za skrót oznaczający współoddziaływanie kilku wymiarów zmian w sferach: rolnictwa (oznaczające wzrost wydajności, konkurencyjności i rozrost gospodarstw, uwalniające zbędną siłę roboczą), techniki (wynalazki i odkrycia pozwalające na wzrost wydajności pracy), funkcjonowania rynku (zwiększenie obrotu $\mathrm{w}$ handlu), transportu (powstanie i rozrost nowych środków transportu - początkowo głównie kolei), ludnościowej - wędrówki ludzi do dużych miast (patrz Majer 2010: 159-168) 
niemobilnym. Nowy typ produkcji otworzył drogę do zmiany specyfiki miasta, zintensyfikował rozpoczęty (zgodnie ze współczesnym rozumieniem tego zjawiska) w XVII wieku w Anglii proces urbanizacji, której - zdaniem Janusza Ziółkowskiego - jednym z czterech wymiarów jest urbanizacja demograficzna, wyrażająca się koncentracją ludności w ośrodkach miejskich na skutek napływu ludności ze wsi (Ziółkowski 1965).

Proces urbanizacji w Polsce $^{2} \mathrm{w}$ porównaniu do krajów Europy Zachodniej postępował z ponad stuletnim opóźnieniem i przybrał odmienną postać. Z względnie intensywnym rozwojem miast w Polsce mamy do czynienia w zasadzie dopiero po zakończeniu II wojny światowej, nie przybrał on jednakże tempa, jakie cechowało miasta Europy Zachodniej, choć w ciągu pięćdziesięciu lat od jej zakończenia nastąpił wzrost wskaźnika urbanizacji o 19\%. Tym, co określało specyfikę powojennego rozwoju miast w Polsce, był rozdźwięk pomiędzy intensywnością i tempem industrializacji a tempem procesu urbanizacji (Szymańska 2008: 134-135). Niski poziom urbanizacji stanowił efekt przede wszystkim polityki państwa, kładącej nacisk na intensywną industrializację. Wysoki i szybki wzrost poziomu industrializacji był możliwy dzięki ograniczeniu nakładów na rozwój miast - ośrodków przemysłowych i ich infrastruktury. Wprowadzenie systemu dojazdów pracowniczych, wspomaganego zakładowymi środkami transportu dowożącymi pracownika do miejsca pracy, a także ograniczenie możliwości meldunku w miastach przy jednoczesnym obowiązku posiadania stałego zamieszkania utrudniały relokację i, co ważniejsze, zmniejszały nakłady na budownictwo. Te swoiste oszczędności stawały się w prosty sposób źródłem nakładów na przemysł (Jałowiecki 2006). Jak podaje Daniela Szymańska, w okresie od 1960 do 1980 roku udział dojeżdżających do pracy w niektórych miastach wynosił 50\% (Szymańska 2008: 135). Uzależnienie rozwoju miasta od przemysłu w okresie powojennym nie tyle nawiązywało do nierozłączności tych dwóch procesów (industrializacji i urbanizacji) w rozwoju miast zachodnioeuropejskich, ile było podporządkowane socjalistycznej ideologii i tym samym odpowiadało koncepcji miasta socjalistycznego. Z punktu widzenia migracji fakt, że to przemysł miał decydować o charakterze i specyfice miasta, oznaczał konieczność, nawet jeśli ograniczonego, to jednak napływu ludności.

Dynamika rozwoju ludnościowego dużych miast $\mathrm{w}$ Polsce $\mathrm{w}$ latach 1950-1999 była zróżnicowana (Petryszyn 2002: 19-21; Parysek 2005: 62-80).

2 Abstrahuje tu od kwestii przebiegu tego procesu na ziemiach polskich $\mathrm{w}$ czasie rozbiorów, po pierwsze ze względu na uwarunkowanie go specyfiką polityki poszczególnych zaborców wobec tych terenów, po drugie ze względu na fakt częściowej lub całkowitej zmiany znaczenia niektórych miast po odzyskaniu niepodległości. 
Największy przyrost ludności duże miasta odnotowały w latach pięćdziesiątych ubiegłego wieku, co wiązało się z jednej strony z odbudową kraju i jego struktury gospodarczej, a z drugiej - z odbudową struktury ludnościowej i towarzyszącym jej wysokim przyrostem naturalnym. $Z$ punktu widzenia założeń formowania społeczeństwa socjalistycznego napływająca ze wsi ludność była podstawą tworzenia niezbędnej dla jego istnienia klasy robotniczej (istniejącej w zalążkowej, znikomej postaci w okresie przed II wojną światową i bezpośrednio po jej zakończeniu; w roku 1938 robotnicy przemysłowi stanowili około $5 \%$ społeczeństwa - w przybliżeniu było ich 1,9 $\mathrm{mln}^{3}$ ). Nowo powstające ośrodki przemysłowe, zlokalizowane przede wszystkim $\mathrm{w}$ dużych miastach, generowały miejsca pracy, a jednocześnie do swego rozwoju potrzebowały, w dużej mierze niewykształconej, siły roboczej. Ułatwiło to migracje ludności przeludnionych wsi (choć nie rozwiązywało samego problemu przeludnienia) do miast i przyczyniło się do zjawisk określanych mianem ruralizacji bądź chłopienia miast (Szczepański 1971; Wasilewski 2006: 54-61).

Kolejne dziesięciolecia to przeplatające się okresy spowolnienia wzrostu (lata sześćdziesiąte i osiemdziesiąte) oraz ożywienia (lata siedemdziesiąte szczególnie w początkowym okresie pokrywającym się z ożywieniem gospodarczym wspomaganym zagranicznymi kredytami). Uzależnienie rozwoju miast od uprzemysłowienia, trwające do końca lat osiemdziesiątych, zmieniło nie tylko ich strukturę przestrzenno-urbanistyczną, ale także społeczno-klasową. Miasto ze względu na wyższy standard życia względnie mniej uciążliwe warunki pracy i możliwość zdobycia wykształcenia (a niekiedy po prostu podstawowych umiejętności pisania i czytania, co miało miejsce szczególnie w pierwszej fazie powojennych migracji) było atrakcyjnym miejscem osiedlenia dla ludności pochodzącej ze wsi. Po początkowym okresie „chaotycznego" osadnictwa miejskiego (przybyła ludność zajmowała dowolnie wybrane, opuszczone mieszkania i domy), jakie charakteryzowało okres odbudowy miast, regulacje $\mathrm{w}$ tym zakresie przyniosło powiązanie napływu ludności z rozbudową przemysłu (Nowakowski 1988). Kolejno powstawały osiedla robotnicze, o charakterystycznym dla poszczególnych okresów powstawania typie zabudowy, zamieszkiwane przez ludność zróżnicowaną społecznie i kulturowo - $\mathrm{w}$ tym sensie $\mathrm{w}$ przestrzeni miejskiej panował względny egalitaryzm, bowiem tworzenie enklaw, przestrzeni elitarnych było nieznaczne (ograniczane także ideologicznie). Z socjologicznego punktu widzenia migracje ludności wiejskiej do miast oznaczały konieczność adaptacji do nowych warunków, integracji w nieznanym środo-

3 Dane te mają charakter szacunkowy, ponadto należy pamiętać, że w okresie międzywojennym statystyki dotyczące podziału klasowo-warstwowego obejmowały nie tylko osoby aktywne zawodowo, ale także ich rodziny (Żarnowski 1973: 32 i n.) 
wisku społecznym, przejęcia nowych wartości, norm i dostosowania zachowań do wymogów miejskiego stylu życia. Wśród najistotniejszych zmian, jakie nastąpiły $\mathrm{w}$ wyniku procesów urbanizacji (zmiany te miały charakter obustronny - dotyczyły zarówno migrantów, jak i ludności miejskiej), wskazywanych w ówczesnych analizach, należy wymienić: rozpad tradycyjnych więzi społecznych, zmianę modelu stosunków społecznych, wzorców zakładania i funkcjonowania rodziny, spadek znaczenia religii i tendencję do sekularyzacji, czy wreszcie pojawienie się nowego - miejskiego stylu życia (m.in. Rybicki 1972; Nowakowski (red.) 1974; Turowski 1976; Szczepański 1964).

Okres stabilizacji rozwoju ludnościowego miast następuje na początku lat dziewięćdziesiątych i jest to $\mathrm{w}$ pewnym sensie dziesięciolecie przełomowe. $W$ końcowej jego fazie są dostrzegalne stopniowe zmiany kierunku migracji z dotychczas dominującego: wieś - miasto lub małe miasto - duże miasto, na: miasto - wieś. Zgodnie z danymi i kryteriami przyjętymi przez Jacka Petryszyna (Petryszyn 2002: 14) dużymi miastami (przekraczającymi 300 tys. mieszkańców) były, w kolejności według wielkości: Warszawa, Łódź, Kraków, Wrocław, Poznań (miasta te w końcu lat dziewięćdziesiątych przekroczyły próg 500 tys. mieszkańców). W tym też czasie kategoria dużych miast powiększyła się o: Gdańsk, Szczecin, Bydgoszcz, Lublin, Katowice, tj. miasta, których liczba mieszkańców w 1950 roku oscylowała w granicach od 117 do 195 tys.

Odwrócenie salda migracji z wieś $\rightarrow$ miasto na miasto $\rightarrow$ wieś, jakie miało miejsce na przełomie XX i XXI wieku (zob. tab. 1), związane bezpośrednio z transformacją ustrojową i intensyfikacją procesów dezindustrializacji, odpowiadało fazie suburbanizacji w modelu cyklu życia miejskiego Leo van den Berga (Berg i in. 1982: 24-45, za: Majer 2010: 153), w której w sensie demograficzno-strukturalnym mamy do czynienia $\mathrm{z}$ rozrostem przestrzennym i ludnościowym przedmieść, kosztem kurczących się ludnościowo obszarów centralnych.

Szczególnie gwałtowny odpływ ludności z miast miał miejsce w okresie od 2001 do 2003 roku. Dane dotyczące całego kraju nie ujawniają zróżnicowania międzywojewódzkiego. Nie we wszystkich województwach już od 2000 roku odnotowywano ujemne saldo migracji dla miast - przez okres pierwszych dwóch, a nawet trzech lat województwa: podlaskie, pomorskie i wielkopolskie, cechowało saldo dodatnie, choć malejące. Zestawienie to uwidacznia także specyfikę województwa mazowieckiego i pośrednio rolę Warszawy jako centralnej metropolii. W okresach silnego odpływu ludności z miast innych województw rosła liczba mieszkańców miast województwa mazowieckiego. Ma to związek z oddziaływaniem ośrodka warszawskiego jako miejsca poszukiwania zatrudnienia, a ponadto $\mathrm{z}$ jego otoczeniem, które stanowią także ośrodki miejskie. 
Tabela 1. Saldo migracji wewnętrznej dla miast w latach 1999-2012 w ujęciu wojewódzkim

\begin{tabular}{|c|c|c|c|c|c|c|c|c|c|c|c|c|c|c|}
\hline \multirow{2}{*}{ Województwo } & \multicolumn{14}{|c|}{$\begin{array}{l}\text { Saldo migracji wewnętrznych dla miast } \\
\text { (w tys.) }\end{array}$} \\
\hline & 1999 & 2000 & 2001 & 2002 & 2003 & 2004 & 2005 & 2006 & 2007 & 2008 & 2009 & 2010 & 2011 & 2012 \\
\hline Polska & 2,8 & $-4,2$ & $-6,5$ & $-17,6$ & $-30,4$ & $-41,6$ & $-32,6$ & $-35,1$ & $-47,9$ & $-38,8$ & $-41,1$ & $-45,9$ & $-39,8$ & $-35,4$ \\
\hline łódzkie & $-0,3$ & $-0,9$ & $-1,1$ & $-2,0$ & $-2,6$ & $-4,0$ & $-3,5$ & $-3,8$ & $-4,7$ & $-3,9$ & $-3,8$ & $-5,0$ & $-4,6$ & $-3,9$ \\
\hline mazowieckie & 6,7 & 6,9 & 7,7 & 8,4 & 8,1 & 6,8 & 8,8 & 9,8 & 6,5 & 4,6 & 4,3 & 4,5 & 7,2 & 6,8 \\
\hline małopolskie & $-1,1$ & $-0,3$ & 0,4 & $-0,7$ & $-1,6$ & $-1,5$ & $-0,9$ & $-1,7$ & $-2,5$ & $-1,9$ & $-1,3$ & $-2,1$ & $-1,4$ & $-1,5$ \\
\hline śląskie & $-3,8$ & $-4,8$ & $-5,1$ & $-5,2$ & $-7,1$ & $-8,0$ & $-7,3$ & $-8,0$ & $-9,3$ & $-7,7$ & $-8,1$ & $-8,5$ & $-8,0$ & $-7,6$ \\
\hline lubelskie & 0,3 & $-0,6$ & $-1,7$ & $-2,6$ & $-3,6$ & $-4,6$ & $-4,5$ & $-4,7$ & $-5,2$ & $-3,8$ & $-3,5$ & $-4,9$ & $-4,4$ & $-4,3$ \\
\hline podkarpackie & $-1,0$ & $-1,4$ & $-2,0$ & $-2,6$ & $-3,4$ & $-3,4$ & $-3,0$ & $-2,5$ & $-2,3$ & $-2,2$ & $-2,7$ & $-2,7$ & $-2,8$ & $-2,2$ \\
\hline podlaskie & 1,7 & 0,9 & 0,7 & 0,2 & $-0,6$ & $-1,2$ & $-1,4$ & $-1,2$ & $-1,6$ & $-1,4$ & $-1,3$ & $-1,7$ & $-1,6$ & $-1,4$ \\
\hline świętokrzyskie & $-1,2$ & $-1,4$ & $-1,6$ & $-2,6$ & $-2,9$ & $-3,3$ & $-2,7$ & $-3,0$ & $-3,1$ & $-2,3$ & $-2,6$ & $-3,1$ & $-2,8$ & $-2,6$ \\
\hline lubuskie & $-0,2$ & $-0,7$ & $-1,1$ & $-1,2$ & $-1,1$ & $-1,8$ & $-1,4$ & $-1,3$ & $-1,7$ & $-1,1$ & $-1,4$ & $-1,5$ & $-1,3$ & $-1,4$ \\
\hline wielkopolskie & 1,3 & 0,2 & 0,4 & $-1,0$ & $-2,5$ & $-3,5$ & $-3,6$ & $-3,7$ & $-5,1$ & $-5,3$ & $-5,2$ & $-5,5$ & $-5,5$ & $-5,2$ \\
\hline zachodniopomorskie & 0,004 & $-0,08$ & $-0,8$ & $-1,6$ & $-2,5$ & $-3,0$ & $-1,9$ & $-2,0$ & $-2,5$ & $-2,2$ & $-2,2$ & $-2,4$ & $-1,9$ & $-1,6$ \\
\hline dolnośląskie & $-1,7$ & $-1,9$ & $-1,1$ & $-3,0$ & $-4,3$ & $-4,7$ & $-3,6$ & $-4,0$ & $-5,3$ & $-3,8$ & $-3,8$ & $-3,7$ & $-3,2$ & $-2,8$ \\
\hline opolskie & $-0,6$ & $-0,5$ & $-0,8$ & $-1,2$ & $-1,4$ & $-1,4$ & $-1,2$ & $-1,6$ & $-2,0$ & $-1,5$ & $-1,6$ & $-1,3$ & $-1,5$ & $-1,2$ \\
\hline kujawsko-pomorskie & 1,4 & $-0,1$ & $-1,3$ & $-2,0$ & $-2,9$ & $-4,2$ & $-3,9$ & $-4,2$ & $-4,2$ & $-3,3$ & $-3,6$ & $-3,7$ & $-3,4$ & $-3,4$ \\
\hline pomorskie & 1,1 & 0,5 & 0,9 & 0,04 & $-1,2$ & $-2,1$ & $-0,8$ & $-1,5$ & $-2,9$ & $-1,5$ & $-1,9$ & $-1,6$ & $-1,8$ & $-1,4$ \\
\hline $\begin{array}{l}\text { warmińsko- } \\
\text {-mazurskie }\end{array}$ & 0,2 & $-0,1$ & $-0,04$ & $-0,6$ & $-0,7$ & $-1,6$ & $-1,5$ & $-1,7$ & $-1,9$ & $-1,6$ & $-2,3$ & $-2,7$ & $-2,6$ & $-1,6$ \\
\hline
\end{tabular}

Źródło: Opracowanie na podstawie: GUS, Bank Danych Lokalnych, www.stat.gov.pl. 
Choć procesy przemian miast w Polsce z powodu wspomnianych uwarunkowań historyczno-politycznych zaczęły następować stosunkowo późno, bo dopiero na początku lat dziewięćdziesiątych ubiegłego wieku, to przebiegały z dużym natężeniem, obejmując wiele sfer życia miasta jednocześnie. Przekształceniom urbanistycznym, związanym ze zmianą struktury gospodarczej, charakteryzującym się między innymi pojawieniem się nowych, architektonicznie „nowatorskich” (jeśli porównać to do wcześniejszego postsocjalistycznego typu zabudowy) budynków - biurowców, centrów usługowych etc., a także zanikiem bądź przekształceniem dawnej zabudowy czy przenoszeniem się zabudowy mieszkaniowej poza granice dużych i średnich miast, towarzyszyły zmiany $\mathrm{w}$ strukturze ludnościowej mieszkańców, związane z różnego rodzaju przemieszczeniami dokonującymi się w przestrzeni miejskiej, mającymi związek również ze zmianami w stratyfikacji społecznej i zaistnieniem nierówności społecznych, których wyrazem stały się grodzone osiedla, ekskluzywne centra handlowo-usługowe $\mathrm{z}$ jednej strony i podupadające centralne dzielnice budynków komunalnych - z drugiej. U podłoża przeobrażeń miast i ich rozrostu leżała transformacja ustrojowa i towarzyszące jej przekształcenia struktury gospodarki, związane z jednoczesnym rozwojem sektora usług i dość gwałtownym zmniejszaniem udziału przemysłu. Przenoszenie zakładów przemysłowych na obrzeża miast skutkowało przenoszeniem miejsc pracy, a więc także relokacją pracowników. Jednocześnie jednak koncentracja rynku usług i finansów w centrach miejskich przyciągała nowych mieszkańców, o określonych kwalifikacjach i kompetencjach. Miasta stały się miejscami wzmożonej ruchliwości, co w szerszym kontekście jest cechą współczesnych społeczeństw doświadczających skutków procesów globalizacji. Ruchliwość, utożsamiana często z mobilnością, oznacza aktywność, jest wiązana z kreatywnością i przedstawiana jako wymóg współczesnych czasów (Urry 2009). Z perspektywy ruchliwości przestrzennej do miast przybywają niezmiennie, pomimo że salda migracji wewnętrznych do miast są ujemne, ci, dla których jest ono obecnie lub ma się stać w przyszłości (choć dla studentów podstawowym motywem przyjazdu do dużych ośrodków miejskich jest edukacja, to część z nich już na początku studiów wiąże swoje przyszłe życie zawodowe $\mathrm{z}$ danym miastem) przede wszystkim miejscem pracy.

Współczesny migrant nie musi jak dawniej na stałe wiązać się z przestrzenią miejską, by być w niej trwale obecnym. Takie możliwości stwarza rozwinięta infrastruktura transportowa. W rezultacie stale powiększa się liczba dojeżdżających do pracy, a więc migrantów wahadłowych, kategorii istniejącej $\mathrm{w}$ przestrzeni miejskiej od dawna. Do rozrostu tej kategorii migrantów w mieście przyczyniły się niewątpliwie zmiany $\mathrm{w}$ systemie gospo- 
Tabela 2. Województwa o największej liczbie dojeżdżających do pracy w 2006 roku

\begin{tabular}{|l|c|c|c|c|c|c|}
\hline Województwo & $\begin{array}{c}\text { Liczba } \\
\text { dojeżdżających } \\
\text { (w tys.) }\end{array}$ & $\begin{array}{c}\text { Udział } \\
\text { w strukturze } \\
\text { dojeżdżających } \\
\text { ogółem } \\
\text { (w \%) }\end{array}$ & $\begin{array}{c}\text { Liczba } \\
\text { miast }\end{array}$ & $\begin{array}{c}\text { Miejsce } \\
\text { w rankingu } \\
\text { województw } \\
\text { o najwięk- } \\
\text { szej liczbie } \\
\text { miast }\end{array}$ & $\begin{array}{c}\text { Miejsce } \\
\text { w rankingu } \\
\text { fojopa } \\
\text { bezrobocia }\end{array}$ & $\begin{array}{c}\text { wojództw } \\
\text { o najwyższej } \\
\text { stopie } \\
\text { bezrobocia }\end{array}$ \\
\hline Polska & $\mathbf{2 2 3 4 , 0}$ & $\mathbf{1 0 0}$ & $\mathbf{8 8 9}$ & $\mathbf{x}$ & $\mathbf{1 4 , 8}$ & $\mathbf{x}$ \\
\hline śląskie & 394,1 & 16,8 & 71 & 4 & 12,7 & 13 \\
\hline wielkopolskie & 269,2 & 11,5 & 109 & 1 & 11,7 & 15 \\
\hline mazowieckie & 265,3 & 11,3 & 85 & 3 & 11,8 & 14 \\
\hline małopolskie & 235,3 & 10,1 & 56 & 6 & 11,3 & 16 \\
\hline dolnośląskie & 175,9 & 7,5 & 91 & 2 & 16,6 & 6 \\
\hline podkarpackie & 170,0 & 7,3 & 45 & 9 & 16,4 & 7 \\
\hline
\end{tabular}

Źródło: Opracowanie na podstawie: Kruszka (red.) 2010: 15; Miasta... 2008; Bank Danych Lokalnych, www.stat.gov.pl.

darczym, a wspomniany wymóg mobilności przyniósł ze sobą konieczność zmiany sposobu myślenia o relacjach z miejscem i przestrzenią. Poszukiwanie pracy poza miejscem zamieszkania staje się $\mathrm{w}$ wielu wypadkach koniecznością, której wraz z rozwojem infrastruktury komunikacyjnej nie musi towarzyszyć zmiana zamieszkania. Dojazdy do pracy są ponadto naturalną konsekwencją procesu suburbanizacji ${ }^{4}$, i to $\mathrm{w}$ następstwie exodusu zamożniejszej, często lepiej wykształconej i młodszej kategorii ludności miast proces ten przybiera na sile. $W$ obu wypadkach migranci nie są zobligowani do zerwania związków z dawnym miejscem. Ciężar życia tych, którzy zdecydowali się na pracę $\mathrm{w}$ mieście, najczęściej pozostaje $\mathrm{w}$ miejscu stałego zamieszkania - tam przebywa ich rodzina, dlatego utrzymują oni z nim względnie trwałe więzi. Miasto jest nade wszystko miejscem pracy i sporadycznie miejscem konsumpcji. Z kolei ci, którzy opuszczają miasto w poszukiwaniu spokojniejszego, zdrowszego życia bądź możliwości spełnienia marzeń o własnym mieszkaniu, na kupno którego w mieście nie pozwalają wyższe ceny, niekoniecznie chcą zrywać związki z miastem. Według badań przeprowadzonych przez Główny Urząd Statystyczny w 2006 roku 1/4 pracowników najemnych dojeżdżała do pracy $\left(2,6\right.$ mln Polaków) ${ }^{5}$ (Miasta... 2008).

4 Proces suburbanizacji, na co wskazuje Jerzy J. Parysek, w Polsce ma złożony charakter i obejmuje proces rozlewania się miast (ubran sprawl), korzystny z punktu widzenia jednostek decydujących się na przeprowadzkę w celu, ogólnie rzecz biorąc, poprawy warunków życia, jednak z ogólnospołecznego punktu widzenia niekorzystny, z powodu choćby nieracjonalnego wykorzystania terenów, zmiany struktury gruntów rolnych czy zagrożeń środowiskowych (Parysek 2008: 13-17; Litwińska 2008).

${ }^{5}$ Badanie opiera się na danych podatników uzyskanych z urzędów skarbowych, a więc w dużym stopniu niweluje problem niekompletnych, nieaktualnych danych gromadzonych w ewidencji ludności. 
Wśród województw o największym natężeniu dojazdów znalazły się głównie (za wyjątkiem województwa podkarpackiego) województwa o największej liczbie miast. Choć ich struktura była zróżnicowana, to poza województwem podkarpackim, w każdym z tych województw było przynajmniej jedno miasto powyżej 200 tys. mieszkańców (wyjątek stanowiły województwa: mazowieckie - dwa oraz śląskie - trzy miasta tej wielkości). Wśród województw o dużej liczbie dojeżdżających (z wyjątkiem województw: dolnośląskiego i podkarpackiego) odnotowano także najniższe stopy bezrobocia w kraju, można więc uznać (biorąc pod uwagę, że nie ma danych $\mathrm{z}$ tego okresu dotyczących motywów takiego działania), że dojazdy były jedną ze strategii radzenia sobie $\mathrm{z}$ bezrobociem. Natomiast wielkość dojazdów nie przekłada się jednoznacznie na stopień mobilności pracowników. Najwyższy udział dojeżdżających w strukturze zatrudnionych odnotowano $\mathrm{w}$ województwie podkarpackim (37\%), stosunkowo wysoki, w granicach 25,1-30\%, w województwach: małopolskim, śląskim, wielkopolskim, opolskim i świętokrzyskim. We wszystkich województwach, niezależnie od skali dojazdów, najistotniejszą rolę pełniły stolice województw (wyjątkiem są dwa województwa posiadające dwa ośrodki centralne: woj. lubuskie - Zielona Góra i Gorzów Wielkopolski oraz woj. kujawsko-pomorskie - Toruń i Bydgoszcz) w każdej z nich liczba przyjeżdżających do pracy kilkakrotnie przewyższała liczbę wyjeżdżających do pracy. Najbardziej rozbudowana struktura dojazdów cechuje największe ośrodki miejskie Polski, tj. Warszawę, Katowice, Kraków, Poznań, Wrocław. Są one miejscem pracy zarówno dla osób mieszkających w ościennych gminach, jak i pochodzących spoza województwa. Zasięg oddziaływania poszczególnych ośrodków jest ponadto ściśle związany z poziomem rozwoju infrastruktury transportowej i liczbą połączeń, co daje przewagę ośrodkom już najsilniej rozwiniętym (między dojazdami a poziomem rozwoju infrastruktury transportowej istnieje sprzężnie zwrotne: dobrze rozbudowana infrastruktura sprzyja dojazdom, ale dojazdy wymuszają także jej rozwój). Jak wskazują analizowane w opracowaniu pod redakcją Kazimierza Kruszki (2010) przypadki Poznania i Krakowa, strefa oddziaływania miasta w zakresie dojazdów koncentruje się głównie w pasie do $50 \mathrm{~km}$, przy czym największe natężenie dojazdów w zależności od specyfiki poszczególnych ośrodków jest obserwowane w granicach do 20-30 km. Wraz ze zwiększaniem odległości natężenie naturalnie maleje, choć w strefie do 100 km można przyjąć, że jest ono wysokie. Trudno oczywiście określić, jaka część z tych, którzy dojeżdżają do pracy, szczególnie powyżej 50 km, robi to regularnie (przy mniejszych odległościach można przypuszczać, że są to dojazdy codzienne), a jaka decyduje się na tymczasowe zamieszkanie 
w miejscu pracy. Trudno także stwierdzić, jaki jest zakres i forma oddziaływania tej kategorii migrantów na miasto, poza wspomnianym rozrostem, modernizacją infrastruktury transportowej i zyskiem ekonomicznym, niemniej jednak jest to kategoria, której wzrostu można się spodziewać.

Współczesne migracje do miast wpisują się ponadto w kontekst metropolizacji jako jednego z kierunków przekształceń przestrzeni miejskiej w Polsce. Aspiracje do bycia metropolią zgłaszają władze wielu miast, jednak z punktu widzenia cech, jakie powinna ona spełniać6, takiego określenia można używać jedynie w odniesieniu do dwóch ośrodków: Warszawy oraz konurbacji śląskiej, a także mniejszych, pełniących role metropolii regionalnych: Krakowa, Łodzi, Trójmiasta czy Poznania. Z perspektywy migranta przekroczenie progu metropolii oznacza wejście bezpośrednio do świata globalnego, świata przepływów, w którym relacje społeczne mają charakter sieciowy, ale także świata zróżnicowanego i podzielonego wewnętrznie, $\mathrm{w}$ którym zajęcie miejsca $\mathrm{w}$ centrum wiąże się $\mathrm{z}$ określonymi wymogami. Powodzenie migracji (w perspektywie jednostkowej jest to równoznaczne $\mathrm{z}$ osiągnięciem sukcesu, indywidualnie definiowanego) nie jest już uwarunkowane jedynie siłą motywacji czy determinacją $\mathrm{w}$ dążeniu do poprawy warunków życia, choć te dwa czynniki niewątpliwie są istotne, ale również posiadanym kapitałem społeczno-kulturowym. Szansę na zajęcie szczególnie wysokiej pozycji mają zatem osoby posiadające zawody, kwalifikacje, kompetencje rzadkie i cenne $\mathrm{z}$ perspektywy funkcjonowania i rozwoju metropolii. Migrant spełniający te kryteria staje się jednocześnie współtwórcą i członkiem już nie klasy średniej czy elity w klasycznym rozumieniu, ale nowoczesnej elity - klasy metropolitalnej. Podstawowym wyróżnikiem położenia klasowego jest posiadanie określonego poziomu oraz rodzaju wiedzy i kwalifikacji, które pozwalają na pozyskanie dobrze płatnej i stabilnej pracy. Najczęściej pracy w środowisku międzynarodowym - w globalnych, międzynarodowych firmach, w których przejście do świata oderwanego od lokalności odbywa się już na poziomie obowiązującego, „urzędowego języka" firmy - najczęściej angielskiego. Funkcjonowanie w środowisku oderwanym od uwarunkowań lokalnych, a więc niezależnym decyzyjnie i organizacyjnie, sprawia, że u tego typu migrantów maleje rola identyfikacji lokalnych i narodowych na rzecz europejskich czy, szerzej, globalnych (Szul

6 Poza kryterium ilościowym, które w wielu definicjach metropolii jest określone na poziomie 500 tys. mieszkańców, wskazuje się na czynniki jakościowe, do których należą: wysoki poziom rozwoju usług, instytucji, wyposażenia, łączących się w sieci globalnych i międzymetropolitalnych powiązań, ale także potencjał innowacyjny połączony ze specyfiką samego miejsca (szerzej na ten temat między innymi: Jałowiecki, Szczepański 2002; Jałowiecki 2007). 
2011: 35). Wysoki poziom zamożności wynikający z ponadprzeciętnych w skali kraju zarobków pozwala na realizację odmiennego stylu życia, cechującego się wysokim poziomem konsumpcji, której towarzyszy wzmożona ruchliwość przestrzenna, przy jednoczesnym ograniczaniu kontaktu $\mathrm{z}$ „innymi”, przyjmującym postać izolacji przestrzenno-społecznej (zamieszkiwanie w luksusowych, zamkniętych osiedlach, korzystanie $\mathrm{z}$ elitarnych szkól, kawiarni, sklepów etc.). Pozwala on ponadto na "nadrobienie” braku kapitału kulturowego w stosunku do stopnia, w jakim posiada go dawna elita (Jałowiecki 2009).

Wymóg wysokich kompetencji sprawia, że metropolia także w znaczeniu migracyjnym przekracza granice państw (Żelazny 2011), stając się magnesem przyciągającym specjalistów z innych krajów. Pojawienie się obcokrajowców w przestrzeni przede wszystkim dużych miast nadaje tym ostatnim znamion wielokulturowości. Wybór polskich ośrodków jako miejsca osiedlenia jest często związany z charakterem pracy, pozycją zawodową, co ze względu na ich specyfikę czyni pobyt tymczasowym, ale wnosi do przestrzeni miejskiej odrębność stylu życia i sposobu nawiązywania relacji społecznych. Niewielka liczba obcokrajowców (według danych Narodowego Spisu Powszechnego z 2011 roku zdecydowana większość urodzonych za granicą ma obywatelstwo polskie, tylko niespełna 7\% (47 tys.) tych osób to cudzoziemcy) stanowi zróżnicowaną kulturowo, społecznie i ekonomiczne grupę. Wśród nich są typowi migranci zarobkowi pochodzący z różnych części świata, część z nich to jednak tzw. wysoko wyspecjalizowani pracownicy pochodzący z UE, zatrudnieni głównie w dużych korporacjach i wchodzący w skład kadry zarządzającej, którzy choć zaliczają się do kultury menadżerskiej, to, jak twierdzi Aneta Piekut (2013), wykazują zróżnicowanie $\mathrm{w}$ zakresie strategii adaptacyjno-integracyjnych wynikające $\mathrm{z}$ ich doświadczenia na rynku pracy i faktu, że poza przestrzenią lokalną funkcjonują także w zróżnicowanych przestrzeniach transnarodowych. Ci, którzy zdecydowali się na założenie rodziny $\mathrm{w}$ Polsce, $\mathrm{w}$ zasadzie podjęli decyzję o integracji, podobną do migrantów zarobkowych. W praktyce takie działanie oznacza budowanie więzi i relacji społecznych $\mathrm{w}$ miejscu zamieszkania, a więc tym samym względną partycypację w życiu miasta. Następuje zatem przekształcanie przestrzeni fizycznej miasta $\mathrm{w}$ przestrzeń społeczną-znaczącą przy zachowaniu relacji z miejscem pochodzenia (Grzymała-Kazłowska 2008). Specyficzną kategorię cudzoziemców stanową migranci czasowi, którzy, jak przyznaje A. Piekut (Piekut 2013: 71), nie są liczną i widoczną kategorią. Ich funkcjonowanie $w$ przestrzeni miejskiej uwidacznia jednak problemy, jakie niesie ze sobą brak zakorzenienia, poczucie tymczasowości. Migranci czasowi ograniczają przestrzeń funkcjonowania przede wszystkim do miejsc, 
w których przebywają podobni do nich: są to miejsca, gdzie jest „wspólnie reprodukowana tymczasowa przestrzeń społeczna migrantów czasowych, co ułatwia wysoko wykwalifikowanym migrantom przystosowanie się do życia w społeczeństwie polskim bez konieczności indywidualnego nabywania zasobów lokalnych" (Piekut 2013: 71). Ponadto w przestrzeniach tych obecność społeczności lokalnej jest znikoma, naturalnie (jeśli są to organizacje skupiające obcokrajowców, szkoły międzynarodowe) bądź z wyboru ograniczana (wybór jest związany z niechęcią do nawiązywania trwalszych relacji $\mathrm{w}$ miejscu pobytu, a wzmagany barierami komunikacyjnymi). Nawiązywane znajomości mają charakter usługowy bądź zawierane są w środowisku Polaków o podobnym stylu życia - mobilnych, posiadających doświadczenia migracyjne, przebywania $\mathrm{w}$ międzynarodowym środowisku, przy czym każdorazowo perspektywa ich trwania nie jest długoterminowa.

Obecność imigrantów - „etników” w mieście tworzy także nową perspektywę rozwojową. Choć trudno określić jednoznacznie ich rzeczywisty wkład w rozwój, to w dużych miastach obserwuje się rosnącą liczbę "etnicznych przedsiębiorców", których do podjęcia własnej działalności gospodarczej zmusiły trudności w znalezieniu pracy bądź dostrzeżenie możliwości zapełnienia luki rynkowej związanej $\mathrm{z}$ zapotrzebowaniem na "etniczne produkty” (Kohlbacher, Matusz-Protasiewicz 2012: 3). Skala tego typu działalności w Polsce jest niewielka i, jak wskazują autorzy opracowania, posługując się danymi z badań przeprowadzonych we Wrocławiu, specyficznie skoncentrowana w sektorze usług. Wśród obcokrajowców zamieszkujących to miasto (poza wysoko wykwalifikowanymi pracownikami korporacji, pochodzącymi ze względu na siedzibę/własność firmy z Japonii, Korei Południowej, Szwecji czy Niemiec i stanowiącymi przede wszystkim kadrę menadżerską) przeważa działalność o profilu gastronomicznym (głównie restauracje i bary szybkiej obsługi serwujące dania kuchni narodowych) bądź językowo-tłumaczeniowym (rzadziej są to właściciele szkół, częściej osoby zatrudnione w nich, przy czym jest to także działalność, którą chętnie podejmują studenci), a także usługi niewymagające wysokich kwalifikacji (np. sprzątanie, prace budowlano-remontowe). Te ostatnie często przybierają jednak formę zatrudnienia nielegalnego (Kohlbacher, Matusz-Protasiewicz 2012: 33-36). Aktywność zawodowa obcokrajowców na wrocławskim rynku pracy w zasadzie oddaje zróżnicowanie tej kategorii ludności dużych miast, dla której to właśnie one są podstawowym miejscem osiedlenia. To jednak, na ile zostaje wykorzystany kapitał społeczno-kulturowy, jakim dysponują obcokrajowcy przebywający w Polsce, pozostaje kwestią niezbadaną. 
Miasta zmieniają nieustannie swój charakter. Podmiotami i twórcami tych zmian są także migranci: ci, którzy stanowią kategorię dawnych mieszkańców, których ruchliwość wymuszona jest „nieprzyjaznością” zmieniającej się przestrzeni miejskiej, ale także ci, którzy choć fizycznie obecni, jednak funkcjonują poza przestrzenią miasta, do którego przybyli, a mimo to mają na nią wpływ. Współczesne przemiany miast są zwrotnie związane z nasiloną tendencją do ruchliwości przestrzennej, która obecnie nie musi oznaczać nawiązywania trwałych i bliskich relacji z „nową" przestrzenią miejską, nawet przy względnie trwałym pobycie, i jednocześnie zerwania relacji $\mathrm{z}$ „dotychczasową" przestrzenią. Tym samym określony zostaje nie tylko nowy wymiar jakości obecności migrantów w przestrzeni miejskiej, ale także charakter jej samej. Choć duże ośrodki miejskie pozostają „miejscami-magnesami", przyciągającymi ludność głównie z mniejszych ośrodków, to w skali ogólnopolskiej migracja przybiera odwrotny kierunek, co nie tyle stanowi przejaw renesansu małych społeczności lokalnych (miejskich czy wiejskich), ile raczej związane jest ze zjawiskiem rozlewania się przedmieść swoistej ekspansji przestrzeni miejskiej na obszar wsi. Ponadto współczesna migracja do miast to zjawisko wieloaspektowe, czego przejawem jest obecność i aktywność etników-obcokrajowców w przestrzeni miejskiej, towarzysząca szczególnie procesom metropolizacji, a zmieniająca $\mathrm{w}$ dłuższej perspektywie sposób myślenia o mieście i działania w nim.

\section{BIBLIOGRAFIA}

Grzymała-Kazłowska A. (2008), Integracja - próba rekonstrukcji pojęcia, [w:] Problemy integracji imigrantów. Koncepcje, badania, polityki, red. A. Grzymała-Kazłowska, S. Łodziński, Wydawnictwa Uniwersytetu Warszawskiego, Warszawa.

GUS, Bank Danych Lokalnych, www.stat.gov.pl.

Jałowiecki B. (2006), Przemiany miast i zbiorowości miejskich, [w:] Wspótczesne społeczeństwo polskie. Dynamika zmian, red. J. Wasilewski, Wydawnictwo Naukowe Scholar, Warszawa.

Jałowiecki B. (2007), Globalny świat metropolii, Wydawnictwo Naukowe Scholar, Warszawa.

Jałowiecki B. (2009), Społeczne oblicza metropolii. Czy istnieje klasa metropolitalna?, [w:] Czy metropolia jest miastem?, red. B. Jałowiecki, Wydawnictwo Naukowe Scholar, Warszawa.

Jałowiecki B., Szczepański M.S. (2002), Miasto i przestrzeń w perspektywie socjologicznej, Wydawnictwo Naukowe Scholar, Warszawa.

Kohlbacher J., Matusz-Protasiewicz P. (2012), The Ethnic Economy in CEE Metropolises: A Comparison of Budapest, Prague, Tallinn and Wroctaw, "CMR Working Papers" 59/17, Ośrodek Badań nad Migracjami, Warszawa, www.migracje.uw.edu.pl (dostęp: 3.09.2013). 
Kruszka K., red. (2010), Dojazdy do pracy w Polsce. Terytorialna identyfikacja przeptywów ludności zwiazanych z zatrudnieniem, GUS, Urząd Statystyczny w Poznaniu, Poznań.

Litwińska E. (2008), Zjawisko urban sprawl - jeden z wymiarów wspótczesnych procesów urbanizacji, [w:] Współczesne kierunki i wymiary procesów urbanizacji, red. J. Słodczyk, M. Śmigielska, Wydawnictwo Uniwersytetu Opolskiego, Opole.

Majer A. (2010), Socjologia i przestrzeń miejska, Wydawnictwo Naukowe PWN, Warszawa.

Miasta w liczbach 2005-2006 (2008), GUS, Urząd Statystyczny w Poznaniu, Warszawa.

Nowakowski S., red. (1974), Przemiany miejskich społeczności lokalnych w Polsce. Materiały z II Ogólnopolskiej Konferencji Socjologów Miasta 30 XI - 1 XII 1972, PWN, Warszawa.

Nowakowski S. (1988), Miasta polskie w okresie powojennym, PWN, Warszawa.

Parysek J.J. (2005), Miasta polskie na przełomie XX i XXI wieku. Rozwój i przeksztatcenia strukturalne, Bogucki Wydawnictwo Naukowe, Poznań.

Parysek J.J. (2008), Urbanizacja i niektóre współczesne idee, koncepcje i modele planowania rozwoju miast, [w:] Wspótczesne kierunki i wymiary procesów urbanizacji, red. J. Słodczyk, M. Śmigielska, Wydawnictwo Uniwersytetu Opolskiego, Opole.

Petryszyn J. (2002), Rozwój demograficzny dużych miast w Polsce, [w:] Demograficzne i społeczne aspekty rozwoju miast, red. J. Słodczyk, Wydawnictwo Uniwersytetu Opolskiego, Opole.

Piekut A. (2013), Wysoko wykwalifikowani wewnątrzunijni migranci w Warszawie - w przestrzeni spotecznej czy w transnarodowej przestrzeni przeptywów?, "CMR Working Papers" 63/121, Ośrodek Badań nad Migracjami, Warszawa, www.migracje.uw.edu.pl (dostęp: 03.09.2013).

Rybicki P. (1972), Społeczeństwo miejskie, PWN, Warszawa.

Szczepański J. (1964), Stan badań socjologicznych nad społecznymi procesami industrializacji, "Studia Socjologiczne" nr 3.

Szczepański J. (1971), Odmiany czasu teraźniejszego, Książka i Wiedza, Warszawa.

Szul R. (2011), Miasto a języki narodowości, [w:] Metropolie mniejszości: mniejszości w metropoliach, red. B. Jałowiecki, E.A. Sekuła, Wydawnictwo Naukowe Scholar, Warszawa.

Szymańska D. (2008), Urbanizacja na świecie, Wydawnictwo Naukowe PWN, Warszawa.

Turowski J. (1976), Ksztattowanie się zbiorowości osiedlowych w wielkich miastach, „Studia Socjologiczne" nr 1.

Urry J. (2009), Socjologia mobilności, Wydawnictwo Naukowe PWN, Warszawa.

Wasilewski J. (2006), Formowanie się nowej struktury społecznej, [w:] Współczesne społeczeństwo polskie. Dynamika zmian, red. J. Wasilewski, Wydawnictwo Naukowe Scholar, Warszawa.

Ziółkowski J. (1965), Urbanizacja, miasto, osiedle, PWN, Warszawa.

Żarnowski J. (1973), Społeczeństwo Drugiej Rzeczypospolitej 1918-1939, PWN, Warszawa 1973.

Żelazny W. (2011), Tubylcy i Barbarzyńcy wieloetnicznych aglomeracji, [w:] Metropolie mniejszości: mniejszości w metropoliach, red. B. Jałowiecki, E.A. Sekuła, Wydawnictwo Naukowe Scholar, Warszawa. 